\title{
POLICYJNE ARCHIWA X JAKO REAKCJA PRAKTYKI ŚLEDCZEJ NA USTAWOWY OBOWIĄZEK WYJAŚNIANIA SPRAW O ZBRODNIE ZABÓJSTWA DO CZASU ICH PRZEDAWNIENIA
}

\begin{abstract}
Streszczenie. W artykule wskazano na istotną rolę, jaką w praktyce śledczej organów ścigania odgrywają policyjne Archiwa X. Autor podkreślił znaczenie tych jednostek zwłaszcza w tych porządkach prawnych, w których ustawodawcy wprowadzają instytucję przedawnienia ścigania. Wskazał też na potrzebę zmian organizacyjnych w obecnie funkcjonującym systemie, prezentując szereg postulatów mogących usprawnić pracę policyjnych zespołów ds. przestępstw niewykrytych.

Slowa kluczowe: przestępstwa niewykryte, Archiwum X, przedawnienie karalności.
\end{abstract}

Wiadomo, że prawdy „należy szukać w czynie”. Jednak w praktyce śledczej - za sprawą niecodziennych, wyszukanych i wyrafinowanych zachowań sprawców przestępstw oraz niejednokrotnie towarzyszącej temu nieporadności organów ścigania - nie daje się jej czasem ustalić. W efekcie wiele głośnych spraw kryminalnych, bulwersujących opinię społeczną nie tylko konkretnego państwa, lecz także społeczności światowej, pozostaje niewyjaśnionych. Problem ten jest tym poważniejszy, jeśli dotyczy spraw o zabójstwo (Gurgul 1977, 4). Taki, niestety, bywa efekt niektórych śledztw. Dzieje się tak, mimo że w organach ścigania panuje swego rodzaju kult śledztwa w sprawach o zabójstwa, nadaje się im priorytet i szczególną rangę, choćby dlatego, że bulwersują opinię społeczną, która interesuje się okolicznościami popełnienia przestępstw i wynikami postępowań (Hołyst 1967, 4). Ciągle nie wiadomo, kto zabił J. Kennedy'ego (O’Reilly, Dugard 2003; Kasprzak, Młodziejowski 2004; Kowalczyk 2013)2 , J. Lennona (King 2010)로. B. Piaseckiego (Lenartowicz 1992; Semczuk 2013) ${ }^{4}$, P. Jaroszewicza (Pytlakowski 2012) czy np. M. Papałę (Marszałek 2008) - albo czy śmierć M. Monroe (Jarecka 2018), W. Sikorskiego (Kisielewski 2005, zob. także np. Baliszewski 2009), A. Mickiewicza (Rymkiewicz 2012),

* Uniwersytet Łódzki, Wydział Prawa i Administracji, Katedra Postępowania Karnego i Kryminalistyki, bsygit@op.pl.

${ }^{1}$ Zob. szerzej: Sygit 2015, 165; A. Asnyk, Huczy woda po kamieniach, 1872, cyt. za: Markiewicz, Romanowski 1990, 29.

${ }^{2}$ Za sprawcę tej zbrodni uznaje się L. H. Oswalda.

${ }^{3} \mathrm{Za}$ zabójstwo to skazano M. D. Chapmana. Z uwagi na to, że był on „chory psychicznie” nie wyklucza się, że zabił S. King, który był fizycznie podobny do Chapmana oraz spotkał się z Chapmanem przed samym zabójstwem.

${ }^{4}$ B. Piasecki, syn działacza PAX-u. Ciało znaleziono w czasie remontu kamienicy. 
Jana Pawła I (Kelly 1997, 457-458) lub J. Arafata ${ }^{5}$ była efektem czynu zabronionego. Sytuacja taka, ze zrozumiałych względów, tworzy różne domysły i podejrzenia o ukrywanie prawdy. Rodzą się teorie spiskowe na dany temat. Podważa to wiarygodność i prestiż organów ścigania. To zaś, że sytuacja ta dotyczy nawet najlepszych policji świata, nie może być pociechą ani wythumaczeniem dla innych organów ścigania. $Z$ problemem tym musi walczyć i rozwiązywać go policja każdego państwa. Jeśli chodzi o Polskę, to w dążeniu do skuteczniejszego wyjaśniania spraw o zbrodnie zabójstwa przyszedł przede wszystkim - i to już w XIX w. - ustawodawca karny. Już bowiem w pierwszym kodeksie karnym, z 1818 r., wprowadził instytucję przedawnienia ścigania, która przedłużała czas wyjaśniania spraw o zabójstwa do 20 lat od chwili ich popełnienia ${ }^{6}$. Po odrodzeniu Rzeczypospolitej kodeksy utrzymały koncepcję przedawnienia zbrodni po 20 latach (takie rozwiązanie przyjął też kodeks karny z 1932 r. i kodeks z 1969 r.), natomiast w aktualnie obowiązującym kodeksie z 1997 r. przyjmuje się 30 lat, gdy „czyn stanowił zbrodnię zabójstwa". W konsekwencji z woli ustawodawcy karnego ściganie sprawcy zabójstwa nie ustaje z chwilą umorzenia śledztwa, np. z powodu niewykrycia sprawcy, ale trwa do upływu 30 lat od chwili jego popełniania. Praktyce pozostaje więc nie marnować tych ,30 lat” przeznaczonych na dokończenie tego, czego nie zrobiono w podstawowym czasie trwania śledztwa. Oznacza to, że obowiązkiem powołanych do tego organów jest aktywne zajmowanie się (kontynuowanie) niewyjaśnionych spraw o zbrodnie zabójstwa do czasu przedawnienia ich ścigania. Sformalizowanym sposobem realizacji tego obowiązku stały się w naszym kraju, funkcjonujące w niektórych komendach wojewódzkich (ostatnio też w Komendzie Głównej) Policji tzw. policyjne Archiwa X. Zapoczątkował je Zespół ds. Niewyjaśnionych Zabójstw funkcjonujący, początkowo nieoficjalnie, w Komendzie Wojewódzkiej Policji w Krakowie od 1999 r. Formalnie, na mocy decyzji Komendanta Wojewódzkiego, działa tam od 16 stycznia 2005 r. Trzeba przyznać, że takie zespoły nie są czymś niezwykłym czy nadzwyczajnym, ale sposobem zorganizowanego działania urzeczywistniającego ustawowy obowiązek wyjaśniania (zajmowania się) zbrodni zabójstwa „aż do końca”. Ich tworzenie nie jest przejawem „dobrej woli organów ścigania", ale koniecznością. W przeciwnym razie przedłużanie przez ustawodawcę okresu ścigania zbrodni zabójstwa do 30 lat od chwili ich popełnienia byłoby fikcją i martwym przepisem, a nie takie jest ratio legis ustawodawcy. Co więcej, ostatnio coraz częściej mówi się o tym, aby zbrodnie zabójstwa nie ulegały przedawnieniu w ogóle (zob. Stańczyk 2018). Z jednej strony prawo dozwalałoby organom ścigania wyjaśnianie tych zbrodni do skutku, lecz z drugiej - brak ograniczenia czasowego mógłby stać się czynnikiem osłabiającym aktywność organów, skoro

${ }^{5}$ Rzeczy osobiste J. Arafata zbadane po jego śmierci nosiły ślady izotopu promieniotwórczego plutonu - zob. Orwellsky.blog.onet.pl [dostęp 1.07.2015].

${ }^{6}$ Art. 208 lit. a Kodeksu Karzącego dla Królestwa Polskiego, Dziennik Praw Królestwa Polskiego 1818, t. V; o rozwoju instytucji przedawnienia w okresie do Kodeksu karnego z 1932 r. zob. szerzej: Sygit 2005, 182-185. 
zawsze miałyby czas na powrót do tych spraw, tyle tylko, że sprawca mógłby już np. nie żyć, a także wiele nieujawnionych dotąd dowodów mogłoby ulec zatarciu. W każdym razie zakładane i rozwijające się placówki (komórki) Archiwum X dają nadzieję, że w końcu akta umorzonych spraw o zbrodnie zabójstwa nie utkną na stałe $\mathrm{w}$ archiwalnych szafach, ale staną się wreszcie przedmiotem codziennego zainteresowania specjalnych komórek, określanych póki co jako „PAX”. Trzeba przy tym uwzględnić, że rozwijanie i doskonalenie funkcjonowania tych grup wymaga wielu zmian organizacyjnych:

1. Policyjnym Archiwom X należałoby nadać rangę Wydziałów ds. Niewyjaśnionych Przestępstw.

2. Wydziały takie powinny być w każdej jednostce policji. Na szczeblach niższych mogłyby to być „komórki”, „oddziały zamiejscowe” itd.

3. Pracami tych wydziałów (komórek, oddziałów) należałoby objąć nie tylko zbrodnie zabójstwa, ale każde przestępstwa, tym bardziej, że w ich przypadku okres do przedawnienia się ich ścigania jest krótszy i wymaga szybszych działań, a nie oczekiwania na ich formalne przedawnienie.

4. Trzeba odstąpić od zasady „subiektywnego wyboru sprawy o zabójstwo”, którą zajmuje się wydział, na rzecz zasady, że zajmuje się każdą sprawą, uwzględniając okres, jaki dał ustawodawca oraz przestrzegając zasady, że nie ma spraw lepszych czy gorszych, za każdą jest ofiara przestępstwa i sprawca.

5. Zajmowanie się sprawami niewyjaśnionymi to nie tylko obowiązek organów ścigania, ale i prokuratorów. Należy zatem albo utworzyć w prokuraturach odpowiednie komórki (wydziały), tak jak w Policji, albo też - wzorem Instytutu Pamięci Narodowej - oddelegować prokuratorów do pracy w wydziałach policyjnych.

6. Praca w wydziałach (komórkach, oddziałach) powinna mieć charakter sformalizowany, musi to być przydział stały, nie z „doskoku”, nie okresowy.

7. Konieczne jest docenienie statusu tych placówek. Praca w ich strukturach powinna być traktowana jako wyróżnienie, a nie jako dodatkowa praca dla osób mniej obciążonych sprawami.

8. Należy dbać o podnoszenie kwalifikacji osób pracujących w omawianych komórkach i ściśle współpracować w tym względzie z laboratoriami kryminalistycznymi dla aktualizacji wiedzy niezbędnej do wyjaśniania „starych spraw", z placówkami naukowymi (w tym kontynuować coroczne konferencje naukowe ${ }^{7}$ ), prowadzić badawcze forum wymiany doświadczeń, prezentacji osiągnięć oraz wypracowywania metod i sposobów poprawy skuteczności pracy tych placówek.

${ }^{7}$ Dotychczas na Wydziale Prawa i Administracji Uniwersytetu Łódzkiego odbyły się dwie ogólnopolskie konferencje poświęcone tzw. policyjnym Archiwom X, zorganizowane przez Zakład Kryminalistyki i Studenckie Koło Kryminalistyków Wydziału Prawa i Administracji UŁ wspólnie z Komendą Wojewódzką Policji w Łodzi, w dniach 25-26 marca 2015 r. oraz 15-16 grudnia 2016 r. We wrześniu 2018 r. planowana jest trzecia taka konferencja, organizowana przez dotychczasowe jednostki wraz z Prokuraturą Krajową i Komendą Główną Policji. 


\section{BIBLIOGRAFIA}

Baliszewski, Dariusz. 2009. Generała Sikorskiego zabili polscy oficerowie. https://wiadomosci. onet.pl/kraj/generala-sikorskiego-zabili-polscy-oficerowie/317zb [dostęp 24.11.2017].

Gurgul, Józef. 1977. Śledztwo w sprawach o zabójstwa. Warszawa: Departament Szkolenia i Doskonalenia Zawodowego Ministerstwa Spraw Wewnętrznych.

Hołyst, Brunon. 1967. Wykrywalność sprawców zabójstw. Warszawa: Wydawnictwo Prawnicze.

Jarecka, Joanna. 2018. „Kryminalistyczna analiza przyczyn śmierci Marilyn Monroe”. Acta Universitatis Lodziensis. Folia Iuridica 83: 91-101.

Kasprzak, Jerzy, Bronisław Młodziejowski. 2004. Anatomia zabójstwa. Nowa rekonstrukcja zamachu na prezydenta J. F. Kennedy'ego. Warszawa: Muza.

Kelly, John N. D. 1997. Encyklopedia papieży. Warszawa: Państwowy Instytut Wydawniczy.

King, Jamie. 2010. Najstynniejsze teorie spiskowe. Tł. Kamil Maksymiuk-Salomoński. Zakrzewo: Wydawnictwo Replika.

Kisielewski, Tadeusz. 2005. Zamach. Tropem zabójców generała Sikorskiego. Poznań: Dom Wydawniczy Rebis.

Kowalczyk, Daniel. 2013. Analiza błędów popełnionych w trakcie śledztwa mającego na celu wyjaśnienie sprawstwa zamachu na Johna F. Kennedy'ego. Praca magisterska napisana pod kierunkiem prof. B. Sygita na Wydziale Prawa i Administracji Uniwersytetu Łódzkiego w Katedrze Postępowania Karnego i Kryminalistyki. Łódź.

Lenartowicz Z. 1992. „Sprawa Piaseckiego”. Rzeczpospolita. 23 lipca.

Markiewicz, Henryk, Andrzej Romanowski. 1990. Skrzydlate słowa. Warszawa: Państwowy Instytut Wydawniczy.

Marszałek, Anna. 2008. Kto zabit Papałę? Moje prywatne śledztwo. Warszawa: Axel Springer Polska. O’Reilly, Bill, Martin Dugard. 2003. Zabić Kennedy'ego. Koniec Camelotu. Warszawa: Burda Książki.

Pytlakowski, Piotr. 2012. „20 lat po zabójstwie Jaroszewiczów”. Polityka. 3 lipca.

Rymkiewicz, Jarosław Marek. 2012. Głowa owinięta koszula. Gdańsk: Wydawnictwo Sic!

Semczuk, Przemysław. 2013. Czarna wołga: kryminalna historia PRL. Kraków: Wydawnictwo Znak.

Stańczyk, Krystian M. 2018. „Instytucja przedawnienia karalności a działalność Policyjnych Zespołów ds. Przestępstw Niewykrytych, tzw. policyjnych Archiwów X”. Acta Universitatis Lodziensis. Folia Iuridica 83: 71-89.

Sygit, Bogusław. 2005. Zbrodnia jako kategoria przestęstwa. Toruń: Wydawnictwo TNOiK - Dom Organizatora.

Sygit, Bogusław (red.). 2015. Złota księga jubileuszowa prof. zw. dr. hab. dr. honoris causa Brunona Hołysta: ...ale prawdy szukaj w czynie. Łódź: Uniwersytet Łódzki, Fundacja „Ubi societas, ibi Ius". 


\author{
Bogustaw Sygit
}

\title{
POLICE X ARCHIVES AS A REACTION OF INVESTIGATIVE PRACTICE TO THE STATUTORY OBLIGATION TO EXPLAIN CASES OF MURDER COMMITTED UNTIL THE STATUTE OF LIMITATIONS EXPIRES
}

\begin{abstract}
The article indicates a significant role of the Police X Archives in the investigative practice of law enforcement authorities. The author emphasized the importance of those units, especially these in legal orders, in which the legislators introduce the institution of prosecution's expiration. The author also mentioned the need of organizational changes in the currently functioning system, while presenting a number of demands that could improve the work of the undetected crime police team.
\end{abstract}

Keywords: undetected offences, Police X Archives, time limitation of punishability. 